\title{
STRUKTUR PASAR DAN DAYA SAING KARET ALAM INDONESIA DI AMERIKA SERIKAT
}

\section{Market Structure and Competitiveness of Indonesian Natural Rubber in the United States}

\author{
${ }^{1}$ Birka Septy Meliany, ${ }^{2}$ Yusman Syaukat, ${ }^{2}$ Hastuti \\ ${ }^{1}$ Departemen Ekonomi Sumberdaya dan Lingkungan, Fakultas Ekonomi dan Manajemen, \\ 2Institut Pertanian Bogor, Kampus IPB Dramaga, Bogor, Jawa Barat 16880, Indonesia \\ Email: septybirka@gmail.com
}

Naskah diterima: 19/08/2021; Naskah direvisi: 10/12/2021; Disetujui diterbitkan: 14/12/2021; Dipublikasikan online: 24/12/2021

\begin{abstract}
Abstrak
Karet alam Indonesia berperan penting dalam meningkatkan perekonomian nasional melalui ekspor karet alam ke berbagai negara, termasuk ke Amerika Serikat. Dalam upaya mengembangkan ekspor karet alamnya, Indonesia perlu melakukan kalkulasi posisi dan daya saing karet alam di antara negara-negara pesaing serta peluang pasarnya ke Amerika Serikat yang memiliki permintaan impor relatif tinggi. Tujuan penelitian ini adalah menganalisis struktur pasar, serta keunggulan komparatif dan kompetitif karet alam Indonesia di pasar Amerika Serikat. Analisis dilakukan selama periode tahun 2008-2019 menggunakan metode Herfindahl Index (HI), Concentration Ratio (CR4), Revealed Comparative Advantage (RCA), Export Product Dynamic (EPD), dan Diamond's Porter. Hasil analisis menunjukkan bahwa struktur pasar karet alam Indonesia cenderung oligopoli. Dibandingkan dengan negaranegara eksportir lainnya, karet alam Indonesia memiliki keunggulan komparatif di pasar Amerika Serikat. Keunggulan kompetitif karet alam Indonesia di Amerika Serikat mengalami penurunan dari posisi lost opportunity pada periode pertama (2008-2011) menjadi retreat pada periode ketiga (2016-2019). Hasil dari Diamond's Porter menunjukkan bahwa terdapat tujuh faktor keunggulan kompetitif dan tiga faktor kelemahan dalam industri karet alam di Indonesia.
\end{abstract}

Kata Kunci: Concentration Ratio, Diamond's Porter, EPD, Herfindahl Index, RCA

\begin{abstract}
Indonesian natural rubber plays a significant role in improving the national economy through exports of natural rubber to various countries, including the United States. In an effort to develop its natural rubber exports, Indonesia needs to calculate the position and competitiveness of natural rubber among competing countries and its market opportunities to the United States, which has a relatively high import demand. The purpose of this study is to analyze the market structure, as well as the comparative and competitive advantages of Indonesian natural rubber in the United States market. The analysis was carried out during the period 2008-2019 using the methods Herfindahl Index (HI), Concentration Ratio (CR4), Revealed Comparative Advantage (RCA), Export Product Dynamic (EPD), and Diamond's Porter. The results of the analysis show that the structure of the Indonesian natural rubber market tends to be an oligopoly. Compared to other exporting countries, Indonesian natural rubber has a comparative advantage in the United States market. The competitiveness of Indonesian natural rubber in the US decline over time from the lost opportunity position in the first period (2008-2011) to retreat in the third period (2016-2019). The Diamond's Porter results
\end{abstract}

https://doi.org/10.30908/bilp.v15i2.623

Published by Trade Analysis and Development Agencies, Ministry of Trade. This is an open access article under the CC BY-NC-SA 4.0 license (http://creativecommons.org/licenses/by-nc-sa/4.0/) 
show that there are seven competitive advantage factors and three weakness factors in Indonesia's natural rubber industry.

Keywords: Concentration Ratio, Diamond's Porter, EPD, Herfindahl Index, RCA JEL Classification: F13, F15, F18

\section{PENDAHULUAN}

Perdagangan

internasional

berkaitan dengan pertukaran barang dan jasa antar negara (Darazo \& Adaramola, 2021) dan secara substansial telah memengaruhi pembangunan ekonomi regional dan kesejahteraan manusia di dunia (Xu et al., 2020). Sektor pertanian memiliki peran penting dalam perdagangan Indonesia (Sugiharti et al., 2020) terutama dalam menghadapi goncangan ekonomi dan terbukti andal dalam pemulihan perekonomian nasional (Basmar et al., 2021). Salah satu subsektor di sektor pertanian yang memiliki potensi besar adalah subsektor perkebunan. Karet alam (400122) merupakan komoditas perkebunan peringkat dua setelah kelapa sawit yang memberikan kontribusi besar dalam penerimaan devisa Indonesia (Alvis \& $\mathrm{Si}, 2021)$. Produksi karet Indonesia tahun 2018 sebesar 3,63 juta ton, sekitar 2,81 juta ton diekspor atau sekitar $77 \%$ dari produksi karet nasional diekspor (Ditjenbun, 2020).

Berdasarkan data dari FAO (2020) Indonesia merupakan negara produsen kedua karet alam di dunia setelah Thailand dengan kontribusi 32\% dari total produksi karet alam dunia. Amerika Serikat menjadi salah satu pangsa pasar karet alam yang mendominasi di dunia (Nainggolan \& Budyanra, 2020) dan juga merupakan negara tujuan importir utama bagi Indonesia. Hal ini dibuktikan dari pangsa pasar Indonesia di pasar Amerika Serikat pada periode 2008 - 2019 yang memiliki nilai kontribusi ekspor karet alam terbesar di antara eksportir lainnya yaitu sebesar $71,96 \%$ (Gambar 1).

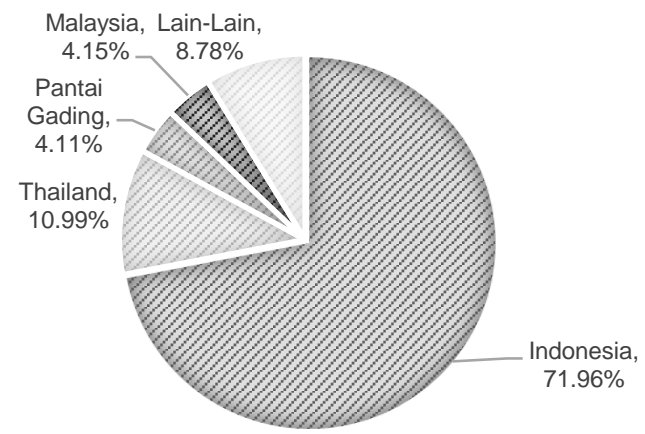

Gambar 1. Pangsa Eksportir Karet Alam Dunia di Amerika Serikat, 2008-2019

Sumber: UN Comtrade (2020), diolah

Kandungan karet alam di dalam ban tidak bisa kurang dari $35 \%$, sehingga ketergantungan terhadap karet alam tinggi (Fardian, 2014). Sebagian besar hasil produksi karet 
alam dunia digunakan untuk membuat ban, sedangkan sisanya dipakai untuk produk lainnya (Setyawati et al., 2014). Salah satu perusahaan ban terbesar di dunia berkantor pusat di Akron, Ohio, Amerika Serikat yaitu "Goodyear Tire and Rubber Company" (Chaplinsky \& Estey, 2017). Hal ini mengindikasikan bahwa penguasaan pasar karet alam di Amerika Serikat menjadi peluang yang besar bagi Indonesia, sehingga terdapat peningkatan terhadap permintaan ekspor yang mendorong daya saing karet alam Indonesia agar mampu bersaing di Amerika Serikat.

Lingkungan persaingan karet alam antar negara eksportir utama di Amerika Serikat perlu diperhatikan dalam struktur pasar. Struktur pasar merujuk pada jumlah dan ukuran distribusi perusahaan dalam pasar serta mudah atau sulitnya masuk dan keluar dari pasar (Hamzah et al., 2018). Rizkyanti (2017) menemukan bahwa struktur industri karet dan barang karet periode 2009 cenderung bersifat oligopoli, sehingga pengawasan yang ketat dari pihak pemerintah diperlukan untuk menghindari dampak-dampak negatif terhadap konsumen. Struktur pasar karet alam dalam lingkup provinsi, hasil sejenis ditemukan dengan adanya lembaga pemasaran yang dominan dalam penentuan harga (Amalia et al., 2013). Ambarwati (2019) menemukan bahwa antara periode 2011 hingga 2015, struktur pasar karet alam masih berbentuk oligopoli melalui perhitungan Herfindahl Index $(\mathrm{HI})$ dan Concentration Ratio (CR).

Kekuatan daya saing komoditas karet alam secara relatif terhadap produk sejenis dari negara lain yang juga menunjukkan posisi komparatif Indonesia sebagai produsen karet alam dibandingkan dengan negara lainnya dalam pasar karet di Amerika Serikat dapat dilihat melalui metode Revealed Comparative Advantage (RCA) (French, 2017). Indonesia memiliki keunggulan daya saing komparatif di sektor primer di perkebunan dengan nilai RCA Indonesia yang lebih tinggi dibanding negara pesaing ASEAN lainnya (Jayadi \& Aziz, 2017). Berdasarkan penelitian Daulika et al., (2020) daya saing ekspor karet alam Indonesia di pasar internasional memiliki keunggulan komparatif dilihat dari tahun 1995-2017 dengan nilai rata-rata $R C A>1$ yaitu sebesar 1,01. Analisis dengan metode Export Product Dynamics (EPD) juga dilakukan guna menganalisis apakah karet alam Indonesia dalam performa yang dinamis atau tidak di Amerika Serikat. Meskipun tidak semua produk 
memiliki nilai ekspor yang tinggi, bukan berarti produk tersebut tidak memiliki daya saing (Prasada \& Dhamira, 2021). Analisis keunggulan kompetitif juga dilengkapi dengan model Diamond's Porter untuk menganalisis kondisi dari faktor-faktor determinan keunggulan kompetitif (Porter, 1990). Berdasarkan paparan tersebut, maka penelitian ini bertujuan untuk menganalisis struktur pasar, serta keunggulan komparatif dan kompetitif karet alam Indonesia di pasar Amerika Serikat periode 2008 hingga 2019.

\section{METODE}

Studi tentang daya saing karet alam telah banyak dilakukan. Beberapa contoh studi yang berkaitan dengan karet alam telah dilakukan oleh Rizkyanti (2017), Muharami \& Novianti (2018), Daulika et al. (2020), dan Nainggolan \& Budyanra (2020). Penelitian ini akan memberikan fokus kajian daya saing yang mendalam ke pasar Amerika Serikat dan mengidentifikasi performa dan kondisi dari faktor determinan karet alam Indonesia.

Data utama penelitian bersumber dari UN-Comtrade, baik data nilai ekspor per negara dan total dunia. Sedangkan data lain untuk melengkapi analisis bersumber dari Food and
Agriculture Organization (FAO), International Monetary Fund (IMF), Kementerian Pertanian, dan World Bank. Terkait dengan agregasi komoditas karet alam maka digunakan kode HS 400122 Technical Specified Natural Rubber (karet alam) agar informasi yang diperoleh menjadi lebih detail dan berdasarkan kepentingannya dalam perdagangan di pasar dunia terutama di pasar Amerika Serikat. Selain itu pertimbangan lain adalah terkait ketersediaan data yang ada.

Jenis data yang digunakan berupa data tahunan (time series) periode 2008 hingga 2019. Observasi tersebut kemudian dibagi menjadi tiga periode analisis dikarenakan peralihan pemerintahan yang terjadi di Amerika Serikat selama empat tahun sekali. Implementasi kebijakan perdagangan sebagian besar berpusat dari pemerintah sebagai pembuat kebijakan, sehingga dapat memengaruhi perdagangan internasional (Sanchez, 2019). Periode pertama dan kedua dalam analisis ini berada pada tahun 2008-2011 dan tahun 2012-2015 yaitu pemerintahan Barack Obama. periode analisis ketiga berada pada tahun 20162019 yaitu pemerintahan Donald Trump. Cakupan level analisis adalah negara tujuan ekspor utama karet alam 
Indonesia yaitu Amerika Serikat. adalah formula Herfindahl Index Negara-negara pesaing Indonesia (Sleuwaegen, 1989):

ditetapkan adalah Thailand, Malaysia, $\quad \mathrm{HI}=\sum_{\mathrm{i}=1}^{\mathrm{n}} \mathrm{Si}^{2}$

dan Pantai Gading dengan asumsi kesamaan dukungan sumber daya dan juga faktor kelengkapan data yang dibutuhkan dibandingkan negaranegara lainnya.

Peta struktur pasar, tingkat daya saing baik komparatif maupun kompetitif maka digunakan metode Herfindahl Index (HI), Concentration Ratio (CR), Revealed Comparative Advantage (RCA), Export Product Dynamics (EPD), dan Diamond's Porter. Metode HI dan CR digunakan untuk menganalisis stuktur pasar. Metode RCA dan EPD digunakan untuk menganalisis daya saing komparatif. Metode Diamond's Porter digunakan untuk menganalisis daya saing kompetitif.

\section{Herfindahl Index (HI) dan Concentration Ratio (CR)}

Analisis struktur pasar karet alam Indonesia dan negara pesaingnya di Amerika Serikat menggunakan indikator Herfindahl Index (HI) dan Concentration Ratio (CR). Pangsa pasar karet dapat diperoleh dengan membandingkan ekspor suatu negara dengan total ekspor karet alam keseluruhan negara eksportir ke pasar Amerika Serikat sebagai negara tujuan ekspor. Berikut

Dimana Si adalah pangsa pasar produk karet alam negara eksportir; $n$ adalah jumlah negara eksportir; i adalah negara eksportir (Indonesia, Thailand, Malaysia, dan Pantai Gading).

HI memiliki kisaran nilai antara 0 dan 1 atau 10.000 yang merupakan kuadrat dari 100\%. Apabila nilai HI mendekati 0 berarti struktur pasar industri terkait cenderung mengarah kepada pasar persaingan (competitive market). Jika nilai $\mathrm{HI}$ mendekati 1 atau 10.000 maka struktur pasar industri tersebut cenderung berkonsentrasi tinggi (Tabel 1).

Tabel 1. Ketentuan Herfindahl Index (HI)

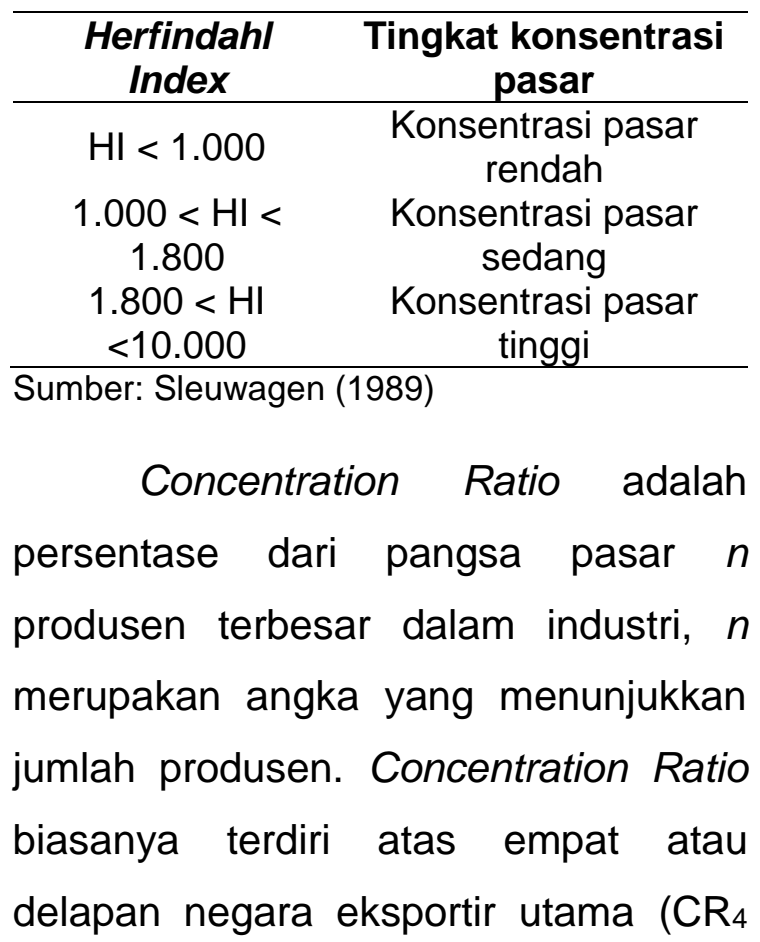


dan $\mathrm{CR}_{8}$ ). Perhitungan Concentration Ratio dapat menggunakan jumlah dari pangsa pasar eksportir di negara tujuan (Sleuwaegen, 1989) yaitu:

$\mathrm{CR}_{4}=\mathrm{Si}_{1}+\mathrm{Si}_{2}+\mathrm{Si}_{3}+\mathrm{Si}_{4}$

Penelitian ini menggunakan Concentration Ratio yang merupakan total pangsa pasar keempat negara eksportir pada tahun 2008-2019. Keempat eksportir yang diteliti adalah Indonesia, Thailand, Malaysia, Pantai Gading.

Tabel 2. Ketentuan Concentration Ratio

\begin{tabular}{|c|c|c|}
\hline CR & $\begin{array}{c}\text { Tingkat } \\
\text { konsentrasi } \\
\text { pasar }\end{array}$ & Struktur pasar \\
\hline $\begin{array}{c}0- \\
50 \%\end{array}$ & $\begin{array}{c}\text { Tingkat } \\
\text { konsentrasi } \\
\text { rendah }\end{array}$ & $\begin{array}{c}\text { Pasar } \\
\text { persaingan } \\
\text { sempurna }\end{array}$ \\
\hline $\begin{array}{l}50- \\
80 \%\end{array}$ & $\begin{array}{l}\text { Tingkat } \\
\text { konsentrasi } \\
\text { sedang }\end{array}$ & $\begin{array}{c}\text { Persaingan } \\
\text { oligopoli }\end{array}$ \\
\hline $\begin{array}{c}80- \\
100 \%\end{array}$ & $\begin{array}{l}\text { Tingkat } \\
\text { konsentrasi } \\
\text { tinggi }\end{array}$ & $\begin{array}{c}\text { Persaingan } \\
\text { oligopoli hingga } \\
\text { monopoli }\end{array}$ \\
\hline
\end{tabular}

Sumber: Sleuwagen (1989)

Nilai $\mathrm{CR}_{4}$ terdiri dari jumlah pangsa pasar empat produsen atau terbesar di dalam sebuah pasar produk. Pada penelitian ini apabila nilai $\mathrm{CR}_{4}$ rendah maka banyak produsen di suatu negara yang mengekspor produk karet alam ke Amerika Serikat sehingga persaingan pasar sangat tinggi, sedangkan nilai
$\mathrm{CR}_{4}$ yang tinggi menunjukkan ada produsen besar yang mendominasi pasar karet alam di Amerika Serikat.

\section{Revealed Comparative Advantage}

Analisis daya saing komoditas ekspor karet alam menggunakan indikator revealed comparative advantage (RCA). Klasifikasi penilaian daya saing komoditas karet alam dikatakan memiliki daya saing tinggi (keunggulan komparatif) apabila nilai RCA di atas 1, sedangkan nilai RCA di bawah 1 maka dikatakan memiliki daya saing rendah. Formula RCA tersebut disajikan sebagai berikut (IMF, 2011):

$R C A=\left(X_{i j} / X_{j}\right) /\left(X_{i w} / X_{w}\right)$.

Dimana $X_{i j}$ adalah nilai ekspor komoditas karet alam negara $j ; X_{j}$ adalah total seluruh komoditas negara $j$, $X_{\text {iw }}$ adalah ekspor komoditas karet alam dunia; $X_{w}$ adalah total seluruh komoditas dunia.

\section{Export Product Dynamic (EPD)}

Metode EPD digunakan sebagai alat untuk mengidentifikasi karet alam Indonesia serta negara pesaingnya yang kompetitif dan berdaya saing tinggi, serta memiliki pertumbuhan produk yang cepat dalam arus perdagangan ekspor di Amerika Serikat. EPD juga dapat mengetahui dinamis 
atau tidaknya performa karet alam, dengan melihat kontinuitas ekspor komoditas tersebut (Tabel 3).

Tabel 3. Matriks posisi pasar EPD

\begin{tabular}{ccc}
\hline $\begin{array}{c}\text { Share of } \\
\text { Indonesia in } \\
\text { emerging market }\end{array}$ & \multicolumn{2}{c}{$\begin{array}{c}\text { Share of natural rubber } \\
\text { in emerging trade }\end{array}$} \\
\cline { 2 - 3 } & Dynamic $(+)$ & $\begin{array}{c}\text { Stagnan } \\
(-)\end{array}$ \\
\hline $\begin{array}{c}\text { Competitiveness } \\
(+)\end{array}$ & Rising star & $\begin{array}{c}\text { Falling } \\
\text { Star }\end{array}$ \\
$\begin{array}{c}\text { Non } \\
\text { competitiveness } \\
(-)\end{array}$ & Lost & Retreat \\
\end{tabular}

Sumber: Esterhuizen (2006)

Empat kategori posisi pasar pada tabel dapat dibentuk ke dalam scatter plot yang merepresentasikan kekuatan bisnis (sumbu $\mathrm{X}$ ) dan daya tarik pasar (sumbu Y) (Gambar 2). Posisi pasar yang ideal pada kuadran I yang menunjukkan posisi rising star, artinya karet alam Indonesia menjadi produk yang dinamis pada pasar yang kompetitif di pasar non tradisional. Kuadran II menunjukkan posisi falling star, artinya perdagangan Indonesia di pasar non tradisional meningkat atau kompetitif, tetapi bukan pada karet alam. Kuadran III menunjukkan posisi lost opportunity artinya hilangnya kesempatan negara Indonesia memperluas pangsa pasar karet alam di pasar non tradisional. Kuadran IV menunjukkan posisi retreat yaitu pasar Indonesia tidak lagi diinginkan di negara non tradisional tersebut.

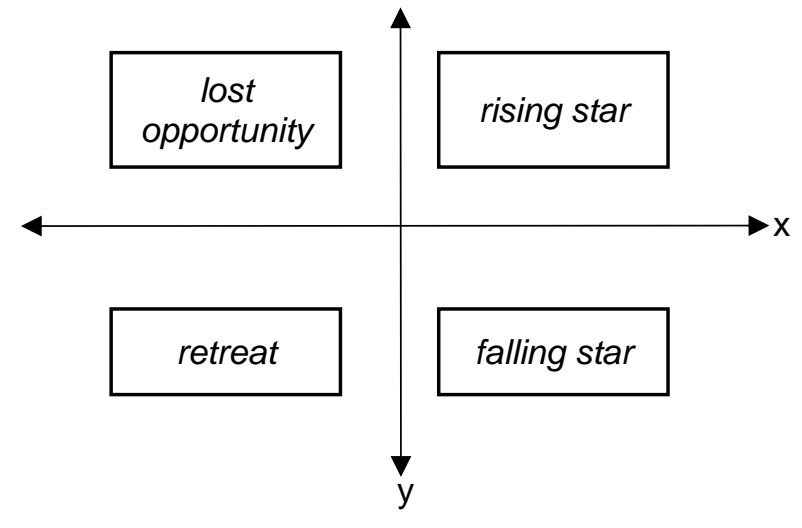

\section{Gambar 2. Matriks EPD}

Sumber: Esterhuizen (2006)

Untuk menentukan sumbu $X$ :

sumbu $X=$

$\frac{\sum_{t=1}^{\mathrm{t}}\left(\frac{\mathrm{Xij}}{\mathrm{Xit}}\right)_{\mathrm{t}} \times 100 \%-\sum_{\mathrm{t}=1}^{\mathrm{t}}\left(\frac{\mathrm{Xij}}{\mathrm{Xit}}\right)_{\mathrm{t}-1} \times 100 \%}{\mathrm{~T}}$

Untuk menentukan sumbu $Y$ :

sumbu Y =

$\frac{\sum_{\mathrm{t}=1}^{\mathrm{t}}\left(\frac{\mathrm{Wtj}}{\mathrm{Wtt}}\right)_{\mathrm{t}} \times 100 \%-\sum_{\mathrm{t}=1}^{\mathrm{t}}\left(\frac{\mathrm{Wtj}}{\mathrm{Wtt}}\right)_{\mathrm{t}-1} \times 100 \%}{\mathrm{~T}}$

Dimana Xij adalah nilai ekspor karet alam negara $j$; Xit adalah nilai ekspor karet alam dunia; Wtj adalah total seluruh komoditas negara $j$, Wtt adalah total seluruh komoditas dunia.

\section{Diamond's Porter}

Diamond's Porter merupakan indikator yang digunakan untuk menganalisis kondisi dari faktor-faktor determinan keunggulan kompetitif kegiatan ekspor karet alam Indonesia ke Amerika Serikat (Porter, 1990). Penjelasan dari keempat atribut utama yang merupakan faktor pendorong daya 
saing karet alam Indonesia di Amerika Serikat sebagai berikut:

a) Kondisi faktor

Kondisi faktor dalam menentukan daya saing adalah faktor produksi karet alam seperti sumberdaya fisik, tenaga kerja, dan modal yang diperlukan dalam kompetisi ekspor karet alam Indonesia ke Amerika Serikat.

b) Kondisi permintaan

Keunggulan kompetitif tercipta ketika pasar lokal untuk karet alam lebih besar daripada pasar internasional dan produsen lokal memberikan perhatian yang lebih besar terhadap pasar Indonesia. Semakin kuatnya pasar Indonesia maka produsen lokal mulai mengekspor karet alam ke Amerika Serikat.

c) Industri terkait dan industri pendukung

Industri terkait dan pendukung, mengacu pada ketersediaan serangkaian dan keterkaitan kuat antara perusahaan-perusahaan eksportir karet alam Indonesia serta industri karet alam di Indonesia yang mendukung ekspor karet alam Indonesia ke Amerika Serikat. Aspek-aspek ini menjadi penelusuran pada faktor dalam industri terkait dan pendukung. d) Struktur, persaingan dan strategi

Strategi perusahaan, struktur, dan persaingan, mengacu pada strategi dan struktur yang ada pada industri karet alam Indonesia sehingga mampu mendorong ekspor karet alam Indonesia ke Amerika Serikat. Struktur akan mengikuti strategi ketika struktur dibangun guna menjalankan strategi. Intensitas persaingan (rivalry) yang tinggi mendorong terwujudnya inovasi.

\section{HASIL DAN PEMBAHASAN}

\section{Struktur Pasar}

Hasil analisis didapatkan nilai ratarata $\mathrm{HI}$ pada periode 2008-2019 komoditas karet alam di pasar Amerika Serikat adalah sebesar 5.367,79 (Tabel 4). Nilai HI berada di antara 1.80010.000 yang menunjukkan bahwa komoditas karet alam oleh negara eksportir utama di pasar Amerika Serikat mengarah pada konsentrasi pasar yang tinggi. Tingginya nilai konsentrasi menggambarkan bahwa industri karet alam merupakan suatu industri yang terkonsentrasi dengan jumlah produsen yang relatif sedikit. Keberadaan kondisi ini juga memperlihatkan bahwa dalam perkembangannya terjadi persaingan yang ketat antar produsen, Indonesia memegang peranan utama sebagai 
supplier karet alam di pasar Amerika Serikat.

Rata-rata rasio konsentrasi empat negara eksportir utama produk karet di pasar Amerika Serikat $\left(\mathrm{CR}_{4}\right)$ pada periode 2008-2019 adalah sebesar 91\%. Nilai yang diperoleh tersebut menggambarkan bahwa 91\% pangsa pasar karet alam Amerika Serikat dikuasai oleh empat produsen terbesar. Dalam periode tersebut, Indonesia, Thailand, Pantai Gading dan Malaysia masing-masing menguasai rata-rata $71,96 \%, \quad 10,99 \%, 4,11 \%$ dan $4,15 \%$ pangsa pasar karet alam di Amerika Serikat. Penguasaan pasar tertinggi Indonesia dan Malaysia terjadi pada tahun 2008 dengan pangsa pasar sebesar $76,74 \%$ dan $6,61 \%$, sedangkan Thailand dan Pantai Gading memiliki pangsa pasar terbesar masing-masing pada tahun 2009 dan 2018 yaitu sebesar 15,11\% dan 6,84\% (Tabel 4).

Tabel 4. Hasil Perhitungan HI dan CR Eksportir Karet Alam Utama Amerika Serikat, 2008-2019

\begin{tabular}{ccr}
\hline Tahun & $\begin{array}{c}\text { Nilai HI } \\
(\%)\end{array}$ & $\begin{array}{c}\text { Nilai CR } \\
(\%)\end{array}$ \\
\hline 2008 & $6.071,08$ & 0,96 \\
2009 & $5.481,01$ & 0,94 \\
2010 & $5.640,12$ & 0,94 \\
2011 & $3.665,31$ & 0,75 \\
2012 & $5.504,03$ & 0,91 \\
2013 & $5.229,01$ & 0,87 \\
2014 & $5.671,97$ & 0,92 \\
2015 & $5.970,52$ & 0,93 \\
2016 & $5.334,40$ & 0,93 \\
\hline
\end{tabular}

\begin{tabular}{ccc}
\hline 2017 & $5.632,20$ & 0,94 \\
2018 & $5.494,03$ & 0,95 \\
2019 & $4.719,80$ & 0,92 \\
\hline Rata-rata & $5.367,79$ & 0,91 \\
\hline
\end{tabular}

Sumber: UN Comtrade (2020), diolah

Hasil perhitungan $\mathrm{HI}$ dan $\mathrm{CR}_{4}$, maka dapat dikatakan bahwa pada periode 2008-2019 struktur pasar karet alam negara eksportir utama yaitu cenderung oligopoli. Sukirno (2010) mendefinisikan pasar oligopoli sebagai pasar yang terdiri atas beberapa penjual untuk satu jenis barang tertentu. Di dalam pasar oligopoli, antara satu produsen dengan produsen lainnya di dalam melakukan kegiatannya tidak terdapat suatu ikatan tertentu (independent action). Dalam pasar persaingan oligopoli, tinggi rendahnya tingkat diferensiasi produk memengaruhi perilaku produsen dalam menentukan output atau harga.

\section{Daya Saing Komparatif (RCA)}

Analisis daya saing karet alam dapat dilihat secara parsial dari pendekatan RCA. Berdasarkan RCA, daya saing pasar karet alam Amerika Serikat didominasi oleh Indonesia dan Pantai Gading (Tabel 5). Secara umum karet alam Indonesia dan Pantai Gading lebih berdaya saing dari produk ekspor lainnya yang diekspor ke pasar Amerika Serikat. Apabila analisis didasarkan 
pada tahun pengamatan, maka periode tahun 2008-2019 memberikan dampak yang bervariasi terhadap daya saing karet alam.

Nilai indeks RCA Malaysia cenderung stabil. Rendahnya nilai Malaysia karena kuantitas ekspor yang yang juga relatif rendah. Salah satu penyebabnya adalah adanya alih fungsi lahan untuk tanaman perkebunan lain yang memiliki prospek lebih besar dibandingkan dengan karet, utamanya kelapa sawit (Charterts et al., 2019). Keterbatasan lahan Malaysia menyebabkan tidak adanya penambahan luas areal tanam perkaretan negara ini selama beberapa tahun. Hasil produksi karet alam domestik Malaysia lebih banyak digunakan untuk kegiatan industri dalam negeri dibandingkan untuk ekspor, karena nilai ekspor untuk barang dari karet lebih tinggi dibanding nilai ekspor karet mentah, sehingga mendorong suatu pengembangan sebuah industri pengolahan karet (ANRPC, 2015). Krisis global yang terjadi pada kuartal ke 3 tahun 2008 memberikan dampak pada ekspor karet alam Indonesia. Hal ini terlihat dari penurunan indeks RCA yang terjadi pada tahun 2009 .
Pada tahun 2009 terjadi penurunan drastis dari 111,47 pada tahun 2008 menjadi hanya sebesar 94,38 . Penurunan nilai ini terjadi akibat dari penurunan kuantitas ekspor karet alam berdasarkan kesepakatan dari ITRC yang merupakan gabungan tiga eksportir terbesar karet alam (Purwaningrat et al., 2020). Terdapat upaya reformasi produksi karet alam yang dilakukan Pantai Gading sejak tahun 2012 dan berimplikasi pada penciptaan kekuatan baru untuk perekonomian negara ini. Hal ini terlihat pada peningkatan drastis ekspor pertanian Pantai Gading ke Amerika Serikat pada tahun 2012 sebesar 72,23 menjadi 102,16 pada tahun 2013 dan terus mengalami peningkatan setiap tahunnya (Radityo, 2015).

Pada tahun 2015 terjadi penurunan drastis yang diakibatkan oleh negara pesaingnya di benua Afrika yaitu Nigeria yang dominan mengekspor karet ke Amerika Serikat, namun kembali meningkat pada tahun 2016 (UN Comtrade, 2020). Keunggulan komparatif yang dimiliki Thailand sebagai produsen terbesar karet alam dunia mengindikasikan bahwa karet alam bukan menjadi produk unggulan yang diekspor ke Amerika Serikat. 
Tabel 5. Hasil Revealed Comparative Advantage (RCA) Eksportir Utama Karet Alam di Amerika Serikat, 2008-2019

\begin{tabular}{crrrr}
\hline \multirow{2}{*}{ Tahun } & \multicolumn{4}{c}{ Nilai RCA (\%) } \\
\cline { 2 - 5 } & Indonesia & Thailand & Malaysia & Pantai Gading \\
\hline 2008 & 111,47 & 11,11 & 5,06 & 17,12 \\
2009 & 94,38 & 12,88 & 4,44 & 24,31 \\
2010 & 90,49 & 10,22 & 4,97 & 44,18 \\
2011 & 72,21 & 8,31 & 3,53 & 39,18 \\
2012 & 101,23 & 9,25 & 4,51 & 72,23 \\
2013 & 94,53 & 5,59 & 4,74 & 102,16 \\
2014 & 100,06 & 6,09 & 5,71 & 107,29 \\
2015 & 98,66 & 7,09 & 4,74 & 89,50 \\
2016 & 90,24 & 10,64 & 3,02 & 130,34 \\
2017 & 91,15 & 9,04 & 3,24 & 104,26 \\
2018 & 93,05 & 10,83 & 2,29 & 149,62 \\
2019 & 88,76 & 12,93 & 3,20 & 126,67 \\
\hline Rata-rata & 93,85 & 9,50 & 4,12 & 83,90 \\
\hline
\end{tabular}

Sumber: UN Comtrade (2020), diolah

\section{Daya Saing Komparatif (EPD)}

Posisi karet alam Indonesia dan negara pesaing selama 2008-2019 ke Amerika Serikat dapat dilihat pada nilai rata-rata hasil EPD karet alam Indonesia dan negara pesaingnya (Tabel 6). Sebagian besar produsen karet berasal dari negara-negara berkembang seperti Indonesia, Thailand, Malaysia dan Pantai Gading.

Pertumbuhan perekonomian AS yang melambat sejak tahun 2009 disebabkan oleh melemahnya belanja konsumsi terutama oleh pemerintah
(Falianty, 2011). Hal ini berdampak negatif terhadap ekspor negara lain terutama Indonesia yang terus menurun. Hal lain yang juga mengancam kesenjangan fiskal pada awal tahun 2013 secara jangka pendek menyebabkan resesi di Amerika Serikat, walau dalam jangka panjang menguntungkan Amerika karena mengurangi tingkat utang secara signifikan. Kondisi ini mengancam ekspor ke Amerika Serikat termasuk dari Indonesia (Ginting, 2017). Defisit transaksi berjalan Amerika Serikat yang 
berkepanjangan karena dianggap krisis keuangan dunia. Hambatan non-tarrif juga diterapkan oleh Amerika Serikat terutama yang berkaitan dengan produk yang harus ramah lingkungan (Dewi,
2018). Hal inilah yang menyebabkan posisi pasar karet alam Indonesia terus menurun tiap tahunnya yang dibahas lebih lanjut pada analisis Diamond's Porter.

Tabel 6. Rata-Rata Hasil EPD Setiap Empat Tahun Komoditas Karet Alam Indonesia Dibandingkan Eksportir Utama Lainnya di Amerika Serikat 2008-2019

\begin{tabular}{lcccc}
\hline Negara & Periode & $\begin{array}{c}\text { Rata-rata } \\
\text { Pertumbuhan } \\
\text { pangsa } \\
\text { pasar karet } \\
(\%)\end{array}$ & $\begin{array}{c}\text { Rata-rata } \\
\text { pertumbuhan } \\
\text { pangsa } \\
\text { pasar total } \\
(\%) \text { (Sumbu }\end{array}$ & Posisi pasar \\
\hline Indonesia & 1 & $-7,34$ & Y) & \\
Thailand & 2 & 5,66 & 0,06 & Lost opportunity \\
& 3 & $-3,44$ & $-0,02$ & Falling star \\
Malaysia & 1 & 0,67 & $-0,01$ & Retreat \\
& 2 & $-0,32$ & 0,00 & Rising star \\
Pantai Gading & 3 & 2,70 & 0,02 & Lost opportunity \\
& 1 & $-1,15$ & 0,04 & Rising star \\
& 2 & 0,32 & $-0,20$ & Retreat \\
& 3 & $-0,38$ & $-0,01$ & Falling star \\
& 1 & 0,68 & $-0,03$ & Retreat \\
& 2 & 0,51 & 0,01 & Rising star \\
& 3 & 0,68 & $-0,01$ & Falling star \\
Sulsing star
\end{tabular}

Sumber: UN Comtrade (2020), diolah

Keterangan:

Sumbu $X$ positif dan sumbu $Y$ positif $=$ rising star

Sumbu $X$ negatif dan sumbu $Y$ positif = lost opportunity

Sumbu $X$ positif dan sumbu $Y$ negatif $=$ falling star

Sumbu $X$ negatif dan sumbu $Y$ negatif $=$ retreat

Periode 1: 2008-2011;

Periode 2: 2012-2015;

Periode 3: 2016-2019

Berbeda dengan Indonesia, penelitian bernama Thailand Rubber pemerintah Thailand sangat fokus Research Institute (Weerathamrongsak terhadap perkembangan tanaman karet dan berusaha melakukan perluasan perkebunan karet di Thailand (Ardanari et al., 2020). Ini menunjukkan bahwa karet alam Thailand mendapat dukungan besar, salah satunya juga adalah replanting melalui suatu lembaga \& Wongsurawat, 2013). Hal yang sama juga diberlakukan oleh pemerintah Pantai Gading, terdapat peningkatan kualitas produk pertanian di negara tersebut. Sedangkan Malaysia produktivitas karet alamnya menurun karena keterbatasan lahan. Malaysia 
juga melakukan kegiatan impor karet alam dengan jumlah yang tinggi. Berdasarkan laporan UN Comtrade (2020), impor karet alam di Malaysia pada 2017 mencapai rekor tinggi 1,1 juta ton, yang melebihi ekspornya. Karet alam yang diimpor Malaysia sebagian besar berupa lateks untuk memenuhi kebutuhan industri, agar para investor tidak pindah ke negara lain. Impor karet alam juga dilakukan untuk pengolahan lebih lanjut melalui pencampuran karet alam yang diproduksi Malaysia untuk kemudian diekspor kembali (Ardanari et al., 2020). Impor karet alam Malaysia mengalami peningkatan untuk beberapa tahun terakhir. Hal inilah yang membuat Malaysia selalu mengalami penurunan posisi pasar ekspor karet alam di Amerika Serikat.

\section{Diamond's Porter}

Kondisi dari faktor-faktor determinan keunggulan kompetitif karet alam Indonesia di pasar Amerika Serikat diidentifikasi melalui empat atribut pada indikator Diamond's Porter, yaitu (1) kondisi faktor (factor conditions); (2) kondisi permintaan (demand conditions); (3) industri pendukung dan terkait (related and supporting industry); dan (4) strategi produsen, struktur,dan persaingan (firms strategy, structure, and rivalry).

\section{a) Kondisi Faktor}

Karet dikenal dengan kualitas elastisnya yang baik sehingga diolah menjadi produk rumah tangga dan industri. Terdapat dua tipe karet yang dikenal luas, karet alam dan karet sintetis. Karet alam dibuat dari getah (lateks) dari pohon karet, sementara tipe sintetis dibuat dari minyak mentah dapat saling menggantikan. Sekitar $70 \%$ dari produksi karet global berasal dari Thailand, Indonesia dan Malaysia (Indonesia Investments, 2017).

Sejak tahun 1980 industri karet Indonesia telah mengalami pertumbuhan produksi yang stabil seiring dengan adanya perluasan lahan produksi yang terjadi selama 2014-2019 (Ditjenbun, 2020). Produktivitas karet di Indonesia memiliki tren pertumbuhan yang terus meningkat meski sekitar $80 \%$ tanaman karet di Indonesia adalah milik rakyat yang kurang dipelihara dengan baik.

Faktor produksi lain dari karet alam yaitu Sumber Daya Manusia (SDM), sehingga perannya juga penting dan berkaitan dengan pengembangan ekspor karet alam. Pertanian di sektor perkebunan merupakan salah satu sektor yang berkontribusi tinggi khsuusnya dalam penyerapan tenaga kerja. Berdasarkan BPS (2020), sektor 
pertanian menyerap 29,96\% dari seluruh tenaga kerja di Indonesia dan menempati posisi pertama. Statistik tersebut menandakan bahwa sektor yang berada di lingkup pertanian seperti perkebunan berperan penting bagi SDM yang ada di Indonesia sebagai sumber pendapatan utama, tetapi kualitas SDM untuk sektor pertanian khususnya subsektor perkebunan masih rendah dengan kisaran hampir $77,75 \%$ tenaga kerja tidak menamatkan pendidikannya sampai SMA.

Terdapat hanya $1,80 \%$ tenaga kerja yang mencapai tingkat pendidikan hingga pada perguruan tinggi. Rendahnya kualitas tenaga kerja akan berdampak pada penurunan produktivitas karena minimnya pengetahuan dan keterampilan terkait dengan teknik produksi (BPS, 2020). Infrastruktur adalah faktor sumber daya fisik yang menunjang kegiatan ekspor karet alam di Indonesia dengan menyediakan akses pengiriman bahan baku.

Temuan penelitian terdahulu menemukan adanya peran dari infrastruktur khususnya penyediaan jalan yang berhubungan dengan nilai ekspor di Indonesia (Amri, 2019). Arus ekspor Indonesia baik secara sektoral dan agregat dipengaruhi oleh variabel infrastruktur secara keseluruhan (Asikin et al., 2016). Berdasarkan data dari World Bank (2018), Indonesia menempati peringkat 3 (tiga) jika dibandingkan dengan kompetitor utamanya di ekspor karet alam periode 2012-2018, sehingga masih kalah bersaing dengan negara produsen lainnya.

Modal merupakan salah satu bagian dari faktor produksi utama selain dari tenaga kerja. Modal dalam pelaksanaan kegiatan subsektor perkebunan terdiri dari penanaman modal dalam negeri dan penanaman modal asing. Subsektor perkebunan dapat memiliki modal investasi dari asing hingga maksimal 95\%, sehingga modal asing juga berperan penting dalam pengembangan perkebunan di Indonesia (Ernawati \& Rusliati, 2019).

$$
\text { Berdasarkan dari Badan }
$$

Koordinasi Penanaman Modal (BKPM) (2020) sektor pertanian, perkebunan dan peternakan merupakan salah satu dari lima sektor primer dalam penanaman modal di Indonesia. selain dari penanaman modal, sektor pertanian, perkebunan dan peternakan juga didukung dengan adanya Kredit Usaha Rakyat (KUR) dalam rangka menambah modal produksi bagi petani. Berdasarkan dari laporan KUR (2020), 
realisasi KUR pada sektor pertanian, perkebunan dan peternakan menunjukkan perkembangan yang positif. Sektor pertanian, perkebunan dan peternakan cenderung lebih stabil dan disertai dengan adanya peningkatan realisasi KUR, sehingga sektor ini memiliki prospek baik di masa mendatang dengan adanya kestabilan pada persentase realisasinya.

b) Kondisi Permintaan

Permintaan karet alam di Indonesia cenderung berasal dari mancanegara dengan persentase yang mencapai $85 \%$ dari produksi karet Indonesia yang kemudian diekspor. Rendahnya konsumsi karet domestik menjadi penyebab Indonesia mengekspor hasil produksi karetnya. Industri hilir karet Indonesia masih belum banyak dikembangkan sehingga tergantung pada impor produk-produk karet olahan (Harahap \& Segoro, 2018).

Sebagian besar produksi karet di Indonesia masih terbatas untuk bahan baku industri ban, alas kaki, dan sarung tangan. Hanya $15 \%$ sisa produksi karet diserap oleh industri hilir dalam negeri dan didominasi oleh industri ban (Perdana, 2019). Setengah dari karet yang diekspor ini dikirimkan ke negaranegara Asia lain, diikuti oleh negaranegara di Amerika Utara dan Eropa.
Salah satu negara impor karet alam Indonesia terbesar adalah Amerika Serikat. Kondisi perdagangan karet alam Indonesia ke Amerika Serikat dapat dilihat pada Tabel 7 .

Tabel 7. Indikator Perdagangan Karet Alam Indonesia ke Amerika Serikat, 2016-2019

\begin{tabular}{cccc}
\hline Tahun & $\mathbf{X}$ & $\mathbf{M}$ & $\begin{array}{c}\text { Neraca } \\
\text { perdagangan }\end{array}$ \\
\hline 2016 & 568,38 & 0 & 568,38 \\
2017 & 577,40 & 0 & 577,40 \\
2018 & 595,43 & 0 & 595,43 \\
2019 & 543,07 & 0 & 543,07 \\
\multicolumn{4}{l}{ Sumber: UN Comtrade (2020), diolah } \\
\multicolumn{4}{c}{ Volume ekspor dan impor pada }
\end{tabular}
Tabel 7 menunjukkan bahwa total volume karet alam Indonesia yang diekspor ke pasar Amerika Serikat dan volume karet alam yang diimpor Indonesia dari Amerika Serikat. Neraca perdagangan diperoleh dari selisih total nilai ekspor dan impor dari Indonesia ke Amerika Serikat. Neraca perdagangan menampilkan informasi bahwa karet alam Indonesia ke Amerika Serikat selalu memiliki nilai positif dari tahun 2016 hingga 2019. Hal tersebut menggambarkan besarnya peran Indonesia dalam suplai karet alam Indonesia ke Amerika Serikat.

c) Industri Pendukung dan terkait

Kegiatan ekspor karet alam Indonesia ke Amerika Serikat memiliki keterkaitan antar industri karet alam baik 
dari segi hulu dan hilir. Karet alam yang diekspor berasal dari tanaman karet untuk diambil getahnya. Selanjutnya getah karet digumpalkan untuk diperoleh hasilnya yang bernama lateks yang kemudian menjadi produk karet alam yang diekspor (Wahyudy, 2018). Kondisi hulu karet alam di Indonesia berkembang dengan meningkatnya faktor produksi karet alam seperti peningkatan luas lahan produksi dan partisipasi tenaga kerja. Kondisi hilir karet alam di Indonesia belum menjadi prioritas pengembangan sehingga industri hilir minim di Indonesia.

Kurangnya industri hilir merupakan salah satu alasan yang menyebabkan penyerapan produksi karet di Indonesia relatif rendah dan berdampak pada kelebihan pasokan di pasar internasional. Pengembangan industri hilir karet alam Indonesia mengalami hambatan dikarenakan sistem insentif yang belum jelas dan minimnya pengawasan terhadap perkebunan karet rakyat sebagai sentra produksi karet alam Indonesia dalam menghasilkan produk-produk karet berkualitas (Bakce et al., 2015).

Faktor teknologi juga menjadi salah satu penyebab dari minimnya industri pendukung terkait dengan karet alam di Indonesia. Teknologi dalam pengolahan karet alam ini disebabkan oleh penelitian dan pengembangan mengenai pengembangan produk industri hilir yang rendah serta minimnya kemampuan SDM untuk mampu mengaplikasikannya (Arianti 2009). Industri karet yang berkembang di Indonesia sebagian besar masih terbatas untuk industri ban, alas kaki, dan sarung tangan (Perdana, 2019). Pengembangan atau diversifikasi industri hilir karet dapat dilakukan dalam rangka meningkatkan serapan produksi karet dalam negeri. Upaya tersebut meliput aspek-aspek fundamental seperti pembiayaan, teknologi, infrastruktur dan regulasi.

d) Strategi produsen, struktur dan persaingan

Hasil analisis $\mathrm{HI}$ dan $\mathrm{CR}_{4}$ dalam penelitian ini menunjukkan bahwa struktur pasar karet alam Indonesia di pasar Amerika Serikat mengarah pada pasar oligopoli. Persaingan negara Indonesia ke Amerika Serikat cenderung berasal dari negara-negara produsen lainnya seperti Thailand, Malaysia dan Pantai Gading. Terdapat dua negara potensial yang dapat menghambat nilai ekspor karet alam Indonesia ke Amerika Serikat. Thailand cenderung mengarah pada pasar Tiongkok karena kebutuhan karet Tiongkok selama setahun 
mencapai 4,3 juta ton. Angka tersebut membuat Tiongkok berada di posisi pertama importir karet dunia disusul oleh Amerika Serikat, Jepang, dan Korea Selatan.

Strategi yang perlu dilakukan Indonesia untuk tetap menjaga pangsa pasar karet alam ke Amerika Serikat adalah menjalin hubungan kerja sama atau bilateral ekonomi yang baik dengan Amerika Serikat. Hal ini didukung oleh kesepakatan perdagangan bebas atau Free Trade Agreement (FTA) Telah mengalami peningkatan dalam dua decade terakhir yang mengindikasikan bahwa arah pengembangan pada perjanjian perdagangan antara dua atau lebih negara mitra dagang secara lebih bebas (Mahdi et al. 2021). Terdapat beberapa kerja sama yang telah terjadi seperti: 1) US-Indonesia Trade and Investment Dialogue, 2) USAID Economic Growth Assistance dan 3) Export Successes for American Businesses. Ketiga bentuk kerja sama mengarah pada perbaikan hubungan bilateral antar kedua negara yang meliputi kegiatan investasi dan perdagangan (Kedubes RI AS, 2012).

Keempat faktor tersebut kemudian disimpulkan dalam satu kerangka model Diamond Porter's. Dua tanda yaitu positif dan negatif digunakan untuk mengindikasikan kondisi pengembangan dari faktor tersebut. Positif ditandakan sebagai suatu keunggulan kompetitif, artinya karet alam Indonesia dapa sedangkan negatif merupakan sisi kelemahan yang perlu dievaluasi kembali. Berdasarkan dari pemaparan dari empat faktor diatas, maka dapat dideskripsikan model Diamond Porter's pada Gambar 3.

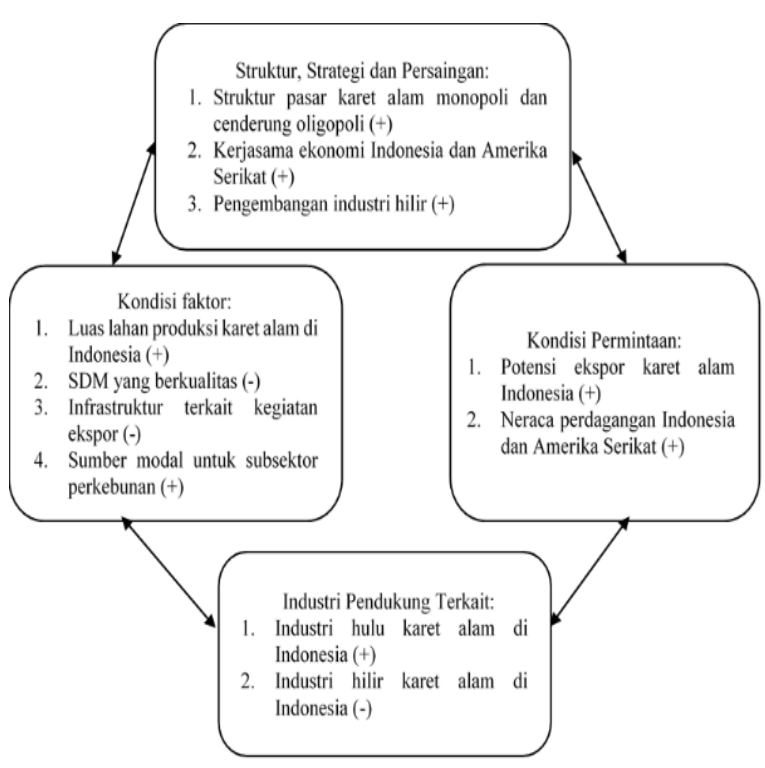

Gambar 3. Model Diamond's Porter

\section{KESIMPULAN DAN REKOMENDASI KEBIJAKAN}

Struktur pasar karet alam di pasar Amerika Serikat berbentuk oligopoli, menunjukkan eksportir utama karet alam ke Amerika Serikat, yaitu Indonesia, Thailand, Malaysia, dan Pantai Gading, memiliki pangsa pasar yang dominan. Berdasarkan hasil analisis, RCA karet alam Indonesia 
bernilai lebih dari satu. Hal ini mengindikasikan bahwa karet alam menjadi produk unggulan yang diekspor Indonesia ke pasar Amerika Serikat dibandingkan dengan produk ekspor lainnya. Keunggulan kompetitif karet alam Indonesia lebih rendah dibandingkan dengan negara pesaing utama, namun pada analisis Diamond's Porter menunjukkan bahwa terdapat sejumlah faktor yang menampilkan keunggulan kompetitif karet alam Indonesia seperti potensi ekspor, neraca perdagangan, kerja sama ekonomi dan luas lahan produksi karet alam.

Secara umum daya saing karet alam Indonesia sangat potensial untuk ditingkatkan di pasar Amerika Serikat di masa mendatang, di samping sumber dayanya yang besar. Upaya-upaya untuk mempertahankan dan meningkatkan potensi tersebut dapat dilakukan melalui (1) perhatian pada teknik replanting dan pohon karet yang sudah berusia tua melalui teknis budidaya teknologi benih dan teknologi pascapanen sehingga mendapatkan benih unggul karet yang baik dan terjangkau terutama bagi perkebunan rakyat milik petani-petani berskala kecil; dan (2) pengembangan industri hilir karet alam untuk meningkatkan nilai tambah dan sekaligus kualitas produk karet alam Indonesia. Penelitian selanjutnya diharapkan melihat aspek kesejahteraan petani karet alam Indonesia karena indikator daya saing yang tinggi belum mencerminkan kesejahteraan petani kecil.

\section{UCAPAN TERIMA KASIH}

Penulis mengucapkan terima kasih kepada Departemen Ekonomi Sumberdaya dan Lingkungan FEM IPB dan team Buletin Ilmiah Litbang Perdagangan (BILP) yang telah memberikan dukungan dan bimbingan kepada penulis. Semoga penelitian ini dapat bermanfaat bagi banyak pihak.

\section{DAFTAR PUSTAKA}

Alvis, R. S. \& Si, M. (2021). Analisis Volume Ekspor Karet di Indonesia. Disertasi. Sumatera Barat: Universitas Bung Hatta.

Amalia, D. N., Nurmalina, R., \& Rifin, A. (2013). Sistem Pemasaran Karet Rakyat di Provinsi Jambi dengan Pendekatan Struktur, Perilaku, dan Kinerja Pasar. Journal of Industrial and Beverage Crops, Vol. 4(3), pp. 237244.

Ambarwati, R. (2019). Respon ekspor karet alam Indonesia. Tesis. Jakarta: Universitas Islam Negeri Syarif Hidayatullah.

Amri, K. (2019). Apakah Infrastruktur Jalan Mempengaruhi Ekspor? Pendekatan Vector Autoregressive. Inovbiz: Jurnal Inovasi Bisnis, Vol. 7(2), pp.166-173.

Arianti, R. K. (2009). Pengembangan Ekspor Produk Komponen Otomotif Berbahan Baku Karet. Buletin IImiah Litbang Perdagangan, Vol. 3(2), pp. 202-220. 
Association of Natural Rubber Producing Countries (ANRPC). (2015). Natural rubber trends and statistics. Kuala Lumpur. Kuala Lumpur: Association of Natural Rubber Producing Countries.

Ardanari, S. D., Mukiwihando, R., \& Ak, S. E. (2020). Daya Saing Ekspor Karet Alam Tiga Negara Itrc (Indonesia, Thailand, Malaysia) di Pasar Internasional Periode 19942018. Jurnal Manajemen Keuangan Publik, Vol. 4(1), pp. 81.

Asikin, Z., Daryanto, A., \& Anggraeni, L. (2016). Pengaruh Infrastruktur dan Kelembagaan terhadap Kinerja Ekspor Agregat dan Sektoral Indonesia. Jurnal Manajemen \& Agribisnis, Vol.13(2), pp. 145-145.

Bakce, D., Syahza, A., \& Hamlin, N. (2015). Strategi pengembangan industri hilir karet alam di Provinsi Riau. In Prosiding Seminar Nasional dan Kongres ISEI XIX (pp. 7-9).

Basmar, E., Purba, B., Nugraha, N. A., Purba, E., Krisnawati, L., Damanik, D., \& Siswanti I. (2021). Perekonomian dan Bisnis Indonesia. Medan: Yayasan Kita Menulis.

Badan Koordinasi Penanaman Modal (BKPM). (2020). Realisasi Investasi. Jakarta : Badan Koordinasi Penanaman Modal.

Badan Pusat Statistik (BPS). (2020). Keadaan Pekerja di Indonesia Agustus 2020. Jakarta: Badan Pusat Statistik.

Chaplinsky, S., \& Estey, W. (2017). Goodyear Tire \& Rubber Company: Follow-On Equity Issue. Darden Business Publishing Cases.

Charters, L. J., Aplin, P., Marston, C. G., Padfield, R., Rengasamy, N., Bin Dahalan, M. P., \& Evers, S. (2019). Peat swamp forest conservation withstands pervasive land conversion to oil palm plantation in North Selangor, Malaysia. International Journal of Remote Sensing, Vol. 40(19), pp. 7409-7438.
Darazo, I. \& Adaramola, A. (2021). Impact of International Trade and Foreign Direct Investment on Economic Growth: The Nigerian Perspective. International Journal of Interdisciplinary Research in Social Science, Vol. 1(1).

Daulika, P., Peng, K. C., \& Hanani, N. (2020). Analysis on Export Competitiveness and Factors Affecting of Natural Rubber Export Price in Indonesia. Agricultural SocioEconomics Journal, Vol. 20(1), pp. 3944.

Dewi, R. (2018). Implementasi Renewable Energy Directive Uni Eropa sebagai Hambatan Non Tarif Perdagangan. Jurnal Hubungan Internasional Interdependence, Vol. $1(2)$.

Direktorat Jenderal Perkebunan (Ditjenbun). (2020). Buku Publikasi Statistik Karet 2018-2020. Jakarta: Direktorat Jenderal Perkebunan.

Ernawati, E., \& Rusliati, E. (2019). Keputusan Investasi dan Pendanaan terhadap Nilai Perusahaan Sub Sektor Perkebunan. Jurnal Riset Bisnis dan Manajemen, Vol. 12(2), pp. 99-107.

Esterhuizen, D. (2006). Measuring and Analysing Competitiveness in the Agribusiness Sector: Methodological and Analytical Framework, University of Pretoria, 107(4), pp. 823-824.

Falianty, T. A. (2011). Desain Kebijakan Publik Dalam Menghadapi Krisis Global. Jurnal Ekonomi \& Kebijakan Publik, Vol. 2(2), pp. 607-626.

Food and Agriculture Organization (FAO). 2020. The countries of the world's largest rubber production centers 2012-2016. http://www.faostat.fao.org.

Fardian, F. (2014). Penjadwalan perawatan komponen kritis mesin produksi remah di pt lembah karet. Disertasi. Padang: Universitas Andalas.

French, S. (2017). Revealed comparative advantage: What is it good for?. Journal of International Economics, Vol. 106, pp. 83-103. 
Ginting, A. M. (2017). Analisis Pengaruh Ekspor terhadap Pertumbuhan Ekonomi Indonesia. Buletin IImiah Litbang Perdagangan, Vol. 11(1), pp. 1-20.

Hamzah, M., Yulius, Y., \& Bidarti, A. (2018). Pengaruh struktur pasar dan tingkat konsentrasi pabrik crumb rubber terhadap perilaku penentuan harga beli bokar petani di Sumatera Selatan: Laporan Penelitian Unggulan Kompetitif Unsri 2018.

Harahap \& Segoro. 2018. Analisis daya saing Komoditas Karet Alam Indonesia ke Pasar Global. Jurnal Transborders Vol. 1(2).

International Monetary Fund (IMF). (2011). Changing Patterns of Global Trade. Washington DC: International Monetary Fund.

Indonesia Investment. (2017). Bisnis Komoditas Karet. https://www.indonesiainvestments.co m/id/bisnis/komoditas/kare t/item185.

Jayadi, A., \& Aziz, H. A. (2016). Peta Persaingan Produk Ekspor Indonesia, Malaysia, Singapura dan Thailand. Jurnal IImu Ekonomi Terapan, Vol. 1(2).

Kedutaan Besar Republik Indonesia untuk Amerika Serikat (Kedubes RI). (2012). US Indonesia Economic and Trade Cooperation Fact. Jakarta: Kedutaan Besar Republik Indonesia.

Kredit Usaha Rakyat (KUR). (2020). Realisasi Kredit Usaha Rakyat. Jakarta : Kredit Usaha Rakyat.

Mahdi, N. N., \& Nurmalina, R. (2021). Trade Creation dan Trade Diversion atas Pemberlakuan ACFTA terhadap Perdagangan Hortikultura Indonesia. Buletin IImiah Litbang Perdagangan, Vol. 15(1), pp. 51-76.

Muharami, G., \& Novianti, T. (2018). Analisis Kinerja Ekspor Komoditas Karet Indonesia ke Amerika Latin. Jurnal Agribisnis Indonesia, Vol. 6(1), 15-26.
Nainggolan, D. G. B. F., \& Budyanra, B. (2020). Daya Saing dan VariabelVariabel yang Memengaruhi Nilai Ekspor Ban Karet Indonesia ke Sepuluh Negara Importir Terbesar di Dunia Tahun 2001-2018. In Seminar Nasional Official Statistics, Vol. 1, pp. 843-854.

Perdana, R. (2019). Kinerja Ekonomi Karet dan Strategi Pengembangan Hilirisasinya di Indonesia. Jurnal Forum Penelitian Agro Ekonomi, Vol. 37(1), pp. 25-39.

Porter, M. E. (1990). The Competitive Advantage of Nation. New York: The Free Press.

Prasada, I. Y., \& Dhamira, A. (2021). The Competitiveness of Natural Rubber by Exporting Countries in the Global Market. In E3S Web of Conferences, Vol. 305, p. 02006.

Purwaninngrat, L., Novianti, T., \& Dermoredjo, S. K. (2020). Dampak Kebijakan International Tripartite Rubber Council (ITRC) terhadap Kesejahteraan Petani Karet Indonesia. Jurnal Ekonomi Pertanian dan Agribisnis, Vol. 4(2), pp. 411-424.

Radityo, S. I., Dwiastuti, R., \& Muhaimin, A. W. (2015). Daya Saing Karet Alam Indonesia di pasar dunia. Habitat, Vol. 25(3), pp. 143-150.

Rizkyanti, A. (2017). Analisis Struktur Pasar Industri Karet dan Barang Karet Periode Tahun 2009. Media Ekonomi, Vol. 18(2), pp. 1-18.

Sanchez, M. (2019). Mexico 's Trade Policy During The Government of President Enrique Pena Nieto (2012-2018). Foro internacional, Vol. 59(3-4), pp. 958987.

Setyawati, I. K., Lin, Y. S., \& Setiawan, B. (2014). Analisis Permintaan Ekspor Karet Alam Indonesia ke Amerika Serikat. Agricultural SocioEconomics Journal, Vol. 14(2), pp. 98.

Siburian, O. (2012). Analisis factor-faktor yang mempengaruhi ekspor karet alam Indonesia ke Singapura tahun 
1980- 2010. Economics Development Analysis Journal, Vol. 1(2).

Sleuwaegen, L. E., De Bondt, R. R., \& Dehandschutter, W. V. (1989). The Herfindahl index and concentration ratios revisited. Antitrust Bull, Vol. 34, pp. 625.

Sugiharti, L., Purwono, R. \& Padilla, M. A. E. (2020). Analysis of Determinants of Indonesian Agricultural Exports. Entrepreneurship and Sustainability Issues, Vol. 7(4), pp. 2676.

Sukirno, S. (2010). Makro Ekonomi, Teori Pengantar. Jakarta: PT. Raja Grafindo Persada.

United Nations Commodity Trade (UN Comtrade). (2021). Data Query of Import and Export. United Nation : United Nations Commodity Trade.
Wahyudy, H. A. (2018). Perkembangan Ekspor Karet Alam Indonesia. Dinamika Pertanian, Vol. 34(2), pp. 87-94.

Weerathamrongsak, P., \& Wongsurawat, W. (2013). The Rubber Industry of Thailand: A Review of Past Achievements and Future Prospects. Journal of Agribusiness in Developing and Emerging Economies.

World Bank. (2018). Logistic Performance Index.https://lpi.worldbank.org/internat io nal/global.

Xu, Z., Li, Y., Chau, S. N., Dietz, T., Li, C., Wan, L., Zhang, J., Zhang, L., Li, Y., Chung, M. G. \& Liu, J. (2020). Impacts of international trade on global sustainable development. Nat. Sustain, Vol. 3, pp. 964-971. 
